Z. Klin. Chem. Klin. Biochem.

13. Jg. 1975 , S. $413-415$

\title{
A Microelectrophoretic Method for the Separation of $\beta$-N-Acetylglucosaminidase A and B from Cultured Human Fibroblasts and Amniotic Cells with the Aid of Polyacrylamide Flat Disc Gels
}

\author{
By S. Singh and $H$. W. Goedde \\ Institute of Human Genetics (Head: Prof. Dr. H. W. Goedde) University of Hamburg, Hamburg
}

(Eingegangen am 17. März/14. Mai 1975)

Summary: A flat gel polyacrylamide microelectrophoretic method is described enabling the separation of human hexosaminidase A and B from cultured human fibroblasts and amniotic cells in parallel multiple channels. The utility of this method in prenatal diagnosis of Tay-Sachs and Sandhoff's disease has been emphasised.

Eine mikroelektrophoretische Methode zur Trennung der $\beta$-N-Acetylglucosaminidase A und B von kultivierten Fibroblasten des Menschen und Amnionzellen mit Hilfe von Polyacrylamid-Diskflachgelen

Zusammenfassung: Eine Mikromethode zur Auftrennung der Hexosaminidasen A und B aus Fibroblastenkulturen und Amnionzellen mittels Polyacrylamidgel-Elektrophorese wird beschrieben; sie ist für die pränatale Diagnose der Tay-Sachs- und Sandhoff-Krankheit geeignet.

\section{Introduction}

The lysosomal enzyme $\beta$-2-acetamido-2-deoxy-D. glucoside hydiolase (E.C. 3.2.1.30), generally known as hexosaminidase, occurs in two or three isoenzyme forms in human tissues $(1,2)$. The isozymes $A$ and $B$ have been clearly characterised from different tissues of normal persons and have been separated by electrophoresis on several media: Starch gel $(1,3,4,5)$; cellulose acetate $(6,7,8)$; polyacrylamide $(9,10,11)$ and by electrofocussing (12).

The isoenzyme levels of this enzyme show changes in $\mathrm{GM}_{2}$ gangliosidosis, a group of lysosomal ganglioside storage diseases (4). In the case of generalised $\mathrm{GM}_{2}$ gangliosidoses a partial deficiency of the enzyme $\mathrm{A}$ has been found (11). Almost complete deficiency of the Enzyme A seems to be responsible for the Tay-Sachs disease (3), while complete absence of the enzymes A and B seems to be the cause of Sandhoff's disease (13).

In this communication a simple method has been reported for the separation of the hexosaminidases from a minute quantity of cultured amniotic cells and fibroblast cells $(100-200)$ by employing a home made multiple channel micro-polyacryl gel slab electrophoresis apparatus.
The polyacrylamide gel was prefered to other media because of a better separation and sharpness of the fluorochrome stained hexosaminidase bands.

Polyacrylamide microelectrophoretic techniques employing micro-capillaries $(14,15)$ and microflatgels of a larger dimension than used by us (16) have been described. In our method preference has been given to flat gels because of the added utility of the simultaneous analysis of several samples and a direct pattern comparison under the same controlled conditions. Other advantages are an easy removal of the gel for rapid staining, convenient optical evaluation and little pattern diffusion. There are no extra complications of this technique other than the few general problems of microgel electrophoresis already described (16). Additional advantages are the saving of cultivated cell material and the possibility of early diagnosis.

\section{Material and Methods}

\section{Cell cultures}

The fibroblast and amniotic cells were cultured as explained earlicr (17). The fibroblast lines from the patients of gencralised gangliosidosis $\mathrm{GM}_{2}$-type, juvonile $\mathrm{GM}_{2}$ gangliosidosis and Tay.Sachs discase werc kindly supplied by Prof. O'Brien, 
Ann Arbor, Michigan, and were further cultivated in our laboratory.

\section{Apparatus}

The apparatus for the micro-polyacrylamide gel slab electrophoresis was constructed from acrylic sheets according to the plan shown in figure 1. It consists of an upper buffer reservoir ( $70 \mathrm{~mm} \times 30 \mathrm{~mm} \times 30 \mathrm{~mm}$ ) having a slit of $3 \mathrm{~mm}$ cut longitudinally across the middle of the base and a lower buffer reservoir $(100 \mathrm{~mm} \times 50 \mathrm{~mm} \times 50 \mathrm{~mm})$ having a platinum wire electrode fixed along the whole length of the bottom, slightly removed from the exact middle of the base plate. The upper electrode is a platinum wire stretched across a $U$ shaped acrylic piece which fits exactly in the middle of the upper tank and rests on two supports in such a way that the electrode dips in the upper buffer solution when the reservoir is $3 / 4$ full. The multiple channel gels are made in cells constructed simply by glueing 2 microcap $1 \mu \mathrm{l}$ capillaries onto the longitudinal ends of a microscope glass slide cover glass, inserting a precision made plastic comb with 5 flat teeth on one end of the cell and glueing the side with the help of Terokal Zement B weiss (a water proof rubber and silicon based cement). Afterwards the cells with polymerised gel ( 2 glass cells with 10 channels) are inserted through the above mentioned slit in the upper buffer reservoir and fixed with the help of the waterproof cement in such a way that about $3 / 4$ of the length of the glass cells protrude out of the reservoir and the arrangement is completely waterproof. The cells are fixed in a vertical position to the base.

\section{Gels}

One step acrylamide medium pore (15\%) separating gels were prepared according to Wilson (18) as described by Maurer (19). A batch of the glass cells were put upright, with the comb portion above, into a small PVC box and the gel solution was introduced gently from below so that the container and the glass cells are gradually filled. Enough solution was added to fill the cells upto the upper end beyond the comb. The gel was polymerised under daylight lamps. The cells were removed from the PVC container and the extra gel was scraped off to separate the cells. The combs were removed very cautiously so that each cell had flat slabs of polymerised acrylamide with 5 channels each.

\section{Electrophoresis}

After fixing the above mentioned glass cells into the apparatus, the channels were dried by means of cellulose acetate paper wicks and the samples equivalent to 100 to 200 fibroblasts (sonified extract or complete cells) are introduced into the channels with the help of a thin capillary and lay ered with a small amount of $100 \mathrm{~g} / \mathrm{l}$ sucrose solution. The lower anodic reservoir was filled with $0.1 \mathrm{~mol} / 1 \mathrm{Tris}-\mathrm{HCl}$ buffer, $\mathrm{pH}$ 8.1. The upper cathodic buffer consisted of $4 \mathrm{~g}$ Tris and $7.2 \mathrm{~g}$ Tricine (Sigma) dissolved in a litre of distilled water at $\mathrm{pH} 8.1$, as used by Friedland et al. (20). After setting the apparatus the glass cells were completely immersed in the buffer so that no excessive heating could be produced in the gel. The electrophoresis was performed for $50 \mathrm{~min}$ in a refrigerator at a voltage of $80 \mathrm{~V}$. The special power supply for the microgel electrophoresis (Ernst Schütt, Göttingen) was employed in this case but any other standard power supply with low adjustment could be used. After completion of the run the cells were removed by cutting them out from the rubber seal in the upper reservoir. One of the cover slip glasses was removed by cutting at the side or simply breaking it with a pincette. The gels were stained using the 4-methylumbelliferyl-2-acetamido-2-deoxy- $\beta-D$-glucopyranoside (Koch, Light Labs, England) for the fluorescent evaluation according to the method fo Friedland et al. (10) or by using the naphthol ASBI derivate of the above compound Koch, Light Labs, England) as a substrate (3).

\section{Results and Discussion}

Figure 2 shows the separation pattern of the hexosaminidase of the normal fibroblast cells, normal fibroblast cells heated to $50^{\circ} \mathrm{C}$ for 2 hours, the fibroblasts from a patient with $\mathrm{GM}_{2}$ generalised gangliosidosis and from a patient with Tay-Sachs disease. It is clear from this study that at this micro level the normal fibroblasts have shown two spots corresponding to the hexosaminidase $A$ and $B$ enzymes as in the normal disc electrophoresis according to Friedland et al. (10). The heated enzyme showed a band corresponding to the hexosaminidase B only, while the fibroblasts from the patient with generalised gangliosidosis showed the two bands corresponding to $\mathrm{A}$ and $\mathrm{B}$. The absolutely heat inactivated fibroblast preparation showed no bands. The Tay-Sachs fibroblast line shiowed only the band corresponding to the hexosaminidase B. These results show that this method can be used for the effective diagnosis

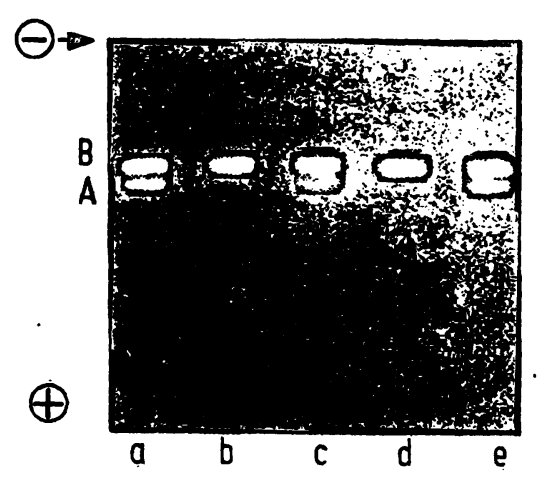

Fig. 2. Microelectrophoresis in flat disc gel photographed in UV light. It shows a pattern of hexosaminidase $A$ and $B$ from cultured fibroblasts from $(a, e)$ normal control cells, (b) normal cells heated to $50^{\circ} \mathrm{C}$ for 2 hours, (c) cells from a patient with generalised gangliosidosis (d) cells from a patient with Tay-Sachs disease. enlargement $2.5 \mathrm{X}$ tank and the separation cells. $A=$ upper buffer tank $B=$ Lower buffer tank $\mathrm{C}=$ Separating cell 
of the Tay-Sachs and Sandhoff's disease, whereby in the latter no enzyme bands should be visible, as in the case of the completely heat inactivated preparation. In these studies with this method the band corresponding to the hexosaminidase $C(2)$ could not be visualised in the human fibroblasts. The presence of this enzyme could also not be detected in our normal cell lines by the conventional disc gel method mentioned above.

The main feature of the present qualitative method is that it could be useful for the early prenatal diagnosis of the Tay-Sachs disease and Sandhoff's disease homozygotes because in this case it is possible to work with a small amount of cultivated amniotic cells. The amniotic cells themselves can also be effectively tested with this method but the diagnosis from the uncultured amniotic cells is not very reliable (21).

\section{Acknowledgement}

We thank the Deutsche Forschungsgemeinschaft for finiancial support.

\section{References}

1. Robinson, D. \& Sterling, J. L. (1968), Biochem. J. 107, 321-327.

2. Poenaru, L. \& Dreyfus, J. C. E. (1973), Clin. Chim. Acta 43, 439-442.

3. Okada, S. \& O'Brien, S. H. (1969), Science 165, 698-704.

4. O’Brien, J. S., Okada, S., Fillerup, D. L., Veath, M. L., Adoranto, B., Brenner, P. H. \& Leroy, J. G. (1971), Science $172,61-64$

5. Navon, R. \& Padeh, B. (1970), Med. J. 4, 17-19.

6. Suzuki, Y. \& Suzuki, K. (1970), Neurology 20, 848-851.

7. Klibansky, C. (1971), Israel J. Med. Sci. 7, 1086-1090.

8. Davidson, R. G. \& Rattazi, M. C. (1972), Clin. Chem. 18, 179-187.

9. Jerome, V. \& Murphy, A. (1972), Life Sci. 11, 309-315.

10. Friedland, J., Perle, G., Saifer, A., Schneck, L. \& Volk, B. (1971), Proc. Soc. Exp. Biol. Med. 136, 1297-1298.

11. Okada, S., Veath, M. L., Leroy, J. \& O'Brien, J. S. (1971), Amer. J. Hum. Genet. 23, 55.

12. Sandhoff, K., Harzer, K., Wässle, W. \& Jatzkewitz, W. (1971), Neurochem. 18, 2469
13. Sanfhoff, K., Andrae, U. \& Jatzkewitz, W. (1968), Life Sci., 7, 283-288.

14. Grossbach, U. (1965), Bioch. Biophys. Acta 107, 180-182.

15. Neuhoff, V. (1968), Arzneim. Forsch. (Drug Res.), 18, $35-41$.

16. Maurer, H., R. \& Dati, F. A. (1972), Analyt. Biochem. 46, 19-32.

17. Singh, S., Willers, I., Schloot, W. \& Goedde, H. W. (1975), Clin. Genetics 8, 18-19.

18. Wilson, C. W. (1969), Annal. Biochem. 31, 506-511.

19. Maurer, H. R. (1970), Disc Electrophoresis. Walter de Gruyter, Berlin, p. 44.

20. Friedland, J., Schneck, L., Saifer, A., Pourfar, M. \& Volk, B. (1970), Clin. Chim. Acta 28, 397-402.

21. Rattazzi, M. C. \& Davidson, R. G. (1972), Prenatal detection of Tay-Sachs disease. Antenatal Diagnosis. Edited by A. Dorfman, Chicago. University of Chicago Press, 1972. 207-211.
Prof. Dr. H. W. Goedde Dr. S. Singh Institut für Humangenetik der Universität Hamburg D-2000 Hamburg 54 Butenfeld 32 
